http://dx.doi.org/10.22319/rmcp.v9i2.4491

Artículo

\title{
Classification, characterisation and strategies for improvement of cattle and sheep pasture systems in marginal areas of Southern Chile
}

Clasificación, caracterización y estrategias para la mejora de los sistemas pastorales de bovinos y ovinos en áreas marginales del sur de Chile

Juan P. Avilez ${ }^{\mathrm{a}}$

Jorge Meyer $^{\mathrm{a}}$

José Nahed ${ }^{\mathrm{b}}$

Francisco A. Ruiz ${ }^{\mathrm{c}^{*}}$

Yolanda Mena ${ }^{\mathrm{d}}$

José M. Castel ${ }^{\mathrm{e}}$

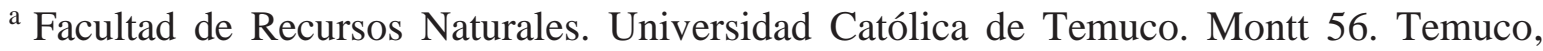
Chile.

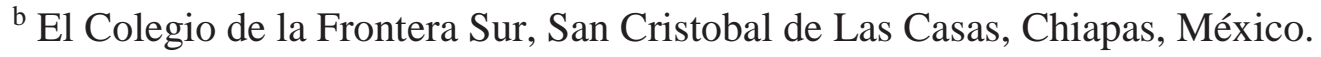

c Instituto de Investigación y Formación Agraria y Pesquera de la Junta de Andalucía (IFAPA). Granada, España.

d Escuela Técnica Superior de Ingenieros Agrónomos (ETSIA), Universidad de Sevilla. Sevilla, España.

${ }^{\text {e }}$ Retired teacher. Sevilla, España.

*Correspondence author: franciscoa.ruiz@juntadeandalucia.es

Funding source: Innova-CORFO Project 11 NTEC 12793 “NODO RÍO IBÁÑEZ”. 


\section{- Abstract:}

Pasture-based livestock systems in farms with medium or low size are especially important in less favored areas and are valuable for society. For these systems to survive, it is necessary to obtain an acceptable level of productivity and ensure commercialization of the products. This study was carried out in the district of Rio Ibáñez, General Carrera Province, in the XI (Aysén) Region of Chile. The sample consisted of 28 small-scale livestock farmers with dualpurpose cattle production; 16 of them also produced sheep for meat. The empirical data produced 55 variables which were subjected to multivariate analysis; three main components were obtained which explain $72.1 \%$ of the variance. By cluster analysis it was obtained four groups with characteristics which varied by farm size, age and personal situation of farmers, farm management and farm profitability. The principal problems found are low productivity in the herds and the poor marketing channels of animals produced. In two groups, due to the low size and poor management, the profitability of the farms is very low and this may compromise their future. To improve production systems, the training and advice of farmers should be strengthened, investment should be supported, especially for young people, and the farmer partnership should be promoted. There is also a need to diversify the families' sources of income (sale of other farm products or handicrafts and touristic activities).

- Key words: Multivariate analysis, Farmer sociological characteristics, Livestock farm management, Farm profit.

\section{- Resumen:}

Los sistemas ganaderos basados en el pastoreo en granjas de mediana o pequeña dimensión tienen especial importancia en las áreas desfavorecidas, y son de gran interés para la sociedad. Para la supervivencia de estos sistemas es preciso obtener una productividad aceptable y asegurar una adecuada comercialización de las producciones. Este estudio se llevó a cabo en la comuna de Rio Ibáñez, provincia General Carrera, ubicada en la XI Región de Chile. La muestra fue de 28 pequeños ganaderos que disponían de bovinos de doble propósito y 16 de ellos también de ovinos de carne. A partir de los datos se obtuvieron 55 variables que fueron sometidas a un análisis multivariante, obteniendo tres componentes principales que explican el $72.1 \%$ de la varianza. Tras un análisis clúster, se obtuvieron cuatro grupos cuyas características varían en cuanto al tamaño de la granja, edad y situación personal del ganadero y manejo y rentabilidad de la granja. Los dos principales problemas generales encontrados fueron la baja productividad de los hatos y los deficientes canales de comercialización de los animales producidos. En dos de los grupos, debido a la reducida dimensión y al mal manejo, la rentabilidad de las granjas es muy baja y ello puede comprometer el futuro de las mismas. Para mejorar los sistemas hay que fortalecer la formación y asesoramiento de los ganaderos, apoyar las inversiones sobre todo para jóvenes, y fomentar el asociacionismo. También interesa la diversificación de las fuentes de ingresos familiares (venta de otros productos de la granja o artesanía y actividades turísticas). 
- Palabras clave: Análisis multivariante, Características sociológicas, Manejo granja, Rentabilidad.

Received 16/05/2017.

Accepted 19/10/2017.

\section{N Introduction}

There is a significant heterogeneity in terms of animal production systems in Latin America due among other reasons to the diversity of environments where they are located, the livestock species used or the objective and specialization of their production ${ }^{(1-4)}$. During recent decades, livestock production has become more intensive worldwide; there is a tendency to see intensive farming as the only possible route to development ${ }^{(5,6)}$. Nevertheless, pasture-based livestock farming systems (PBLFS) are still important ${ }^{(7)}$.

A large proportion of these grazing systems function with low inputs; in general they produce dual-purpose or exclusively meat animals and are located in less favoured areas, e.g. dry or mountainous zones ${ }^{(2,7,8)}$. It is in the interests of society that PBLFS should be maintained: they make use of resources which otherwise would be wasted, they also help to prevent depopulation and maintain environmental equilibrium and produce high quality food $\mathrm{d}^{(9,10)}$.

As it is explained by the literature, problems for the maintenance of PBLFS are various: i) low farm profit, ii) lack of generational relief, iii) difficulty accessing land ownership, iv) scarce technification and professionalization of farmers and v) lack of adequate commercialization channels ${ }^{(9,11,12)}$.

Classification and characterisation of livestock production systems allow to understand their functioning, limitations, potential and opportunities for development or improvement under existing circumstances. The object of the present work was to classify and characterise the PBLFS for cattle and sheep, either for meat or dual-purpose, in a less favoured zone of Southern Chile and to establish proposals for improving the different systems. 


\section{Material and methods}

\section{- Study area, data collection and identification of variables for analysis}

The study was carried out in the Rio Ibáñez Commune located within the Region Aysén del General Carlos Ibáñez del Campo of Chile, 48 $16^{\prime} 00^{\prime \prime} \mathrm{S}, 71^{\circ} 56^{\prime} 00^{\prime \prime} \mathrm{E}$ (Figure 1). It is one of the biggest regions in Chile (14\% of the country), with almost one million ha devoted to farming, especially cattle and sheep-farming for meat and wool ${ }^{(13)}$. The study region is cold steppe with average temperature $6.4^{\circ} \mathrm{C}$ and precipitation of $612 \mathrm{~mm}$. The minimum temperature can fall to $-37^{\circ} \mathrm{C}$.

Figura 1: Location of the study area within the Rio Ibañez Commune (Region Aisén del General Carlos Ibáñez del Campo of Chile)

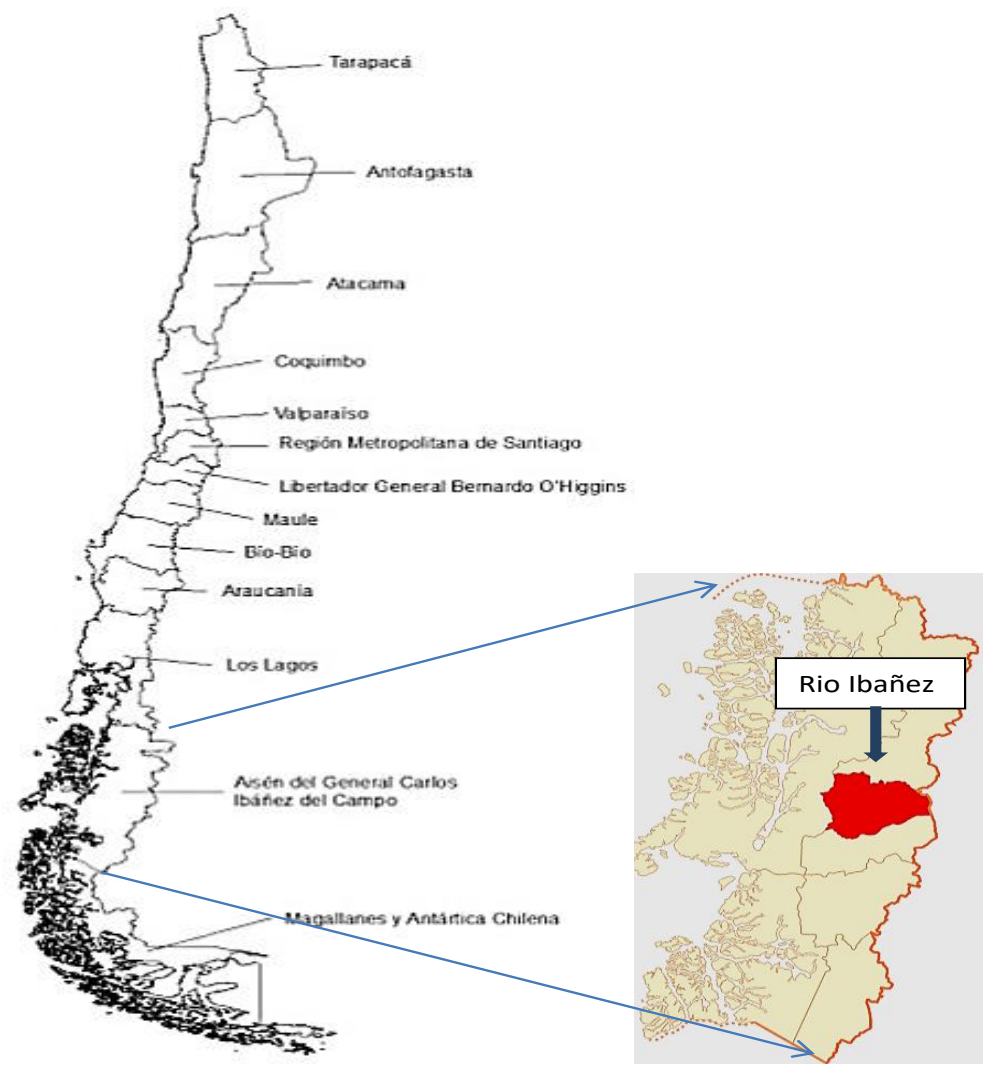


In 2012, 28 producers with bovine presence were interviewed for the "Nodo Río Ibañez" programme, the object of which was to transfer technological knowledge to sheep and cattle producers. They were chosen at random from a total of 230 of the study area (SA), ie $12 \%^{(14)}$. The questionnaire used included the following aspects of the livestock production unit (LPU) survey: (i) Sociological; (ii) Infrastructures, facilities and farm size; (iii) Management variables (feeding, reproduction and health); and (iv) Commercialization and economic variables. From data obtained of this questionnaire, a database with a total of 55 variables was drawn up, being 30 quantitative and 25 qualitative. Of the qualitative variables, 22 are binary (yes $=1$ or no= 0 answers), two have three options and one has four options. Each option of these last variables has been converted into binary. All variables are showed in Tables 1 to 4.

Table 1: Sociological variables for the whole study sample and each group of farms or livestock production units (cluster)

\begin{tabular}{|c|c|c|c|c|c|}
\hline Variables & All groups & Cluster 1 & Cluster 2 & Cluster 3 & Cluster 4 \\
\hline No. farms & 28 & 5 & 11 & 5 & 7 \\
\hline Producer's age, years ** & $50( \pm 3)$ & $51^{\mathrm{ab}}( \pm 9)$ & $39 b( \pm 1)$ & $59^{\mathrm{a}}( \pm 5)$ & $60^{a}( \pm 2)$ \\
\hline Number of family members & $4.2( \pm 0.3)$ & $3.4( \pm 0.5)$ & $4.5( \pm 0.6)$ & $4.2( \pm 0.8)$ & $4.3( \pm 0.6)$ \\
\hline \multicolumn{6}{|l|}{ Person in charge of the farm: } \\
\hline Woman living alone, $\%+$ & $39( \pm 9)$ & $80^{a}( \pm 20)$ & $45^{\mathrm{ab}}( \pm 16)$ & $20^{\mathrm{ab}}( \pm 02)$ & $14^{\mathrm{b}}( \pm 14)$ \\
\hline Husband runs the farm, $\%$ & $46( \pm 10)$ & $20( \pm 20)$ & $46( \pm 16)$ & $60( \pm 25)$ & $57( \pm 20)$ \\
\hline Wife runs the farm, $\% \#$ & $14( \pm 7)$ & 0 & $9( \pm 9)$ & $20( \pm 20)$ & $29( \pm 18)$ \\
\hline \multicolumn{6}{|l|}{ Territorial base } \\
\hline Owned, \% & $64( \pm 49)$ & $80( \pm 20)$ & $55( \pm 16)$ & $60( \pm 25)$ & $71( \pm 18)$ \\
\hline Rented, \% & $4( \pm 4)$ & 0 & $9( \pm 9)$ & 0 & 0 \\
\hline Belonging to family group, $\%$ & $18( \pm 7)$ & 0 & $18( \pm 12)$ & $40( \pm 25)$ & $14( \pm 14)$ \\
\hline Inheritance process, $\%$ & $14( \pm 7)$ & $20( \pm 20)$ & $18( \pm 12)$ & 0 & $14( \pm 14)$ \\
\hline Secondary or higher education, \% \#\# * & $54( \pm 10)$ & $60^{\mathrm{ab}}( \pm 25)$ & $82^{\mathrm{a}}( \pm 12)$ & $40^{\mathrm{ab}}( \pm 25)$ & $14^{b}( \pm 14)$ \\
\hline There is hired labour, $\%$ * & $18( \pm 7)$ & $20^{\mathrm{ab}}( \pm 20)$ & $g^{b}( \pm 9)$ & $60^{\mathrm{a}}( \pm 25)$ & $0^{\mathrm{b}}$ \\
\hline Has done training courses, $\%$ * & $61( \pm 9)$ & $60^{\mathrm{ab}}( \pm 25)$ & $64^{\mathrm{ab}}( \pm 15)$ & $100^{\mathrm{a}}$ & $29^{b}( \pm 18)$ \\
\hline $\begin{array}{l}\text { Farmers believe that the farm will } \\
\text { continue in future generations, } \% \text { * }\end{array}$ & $86( \pm 7)$ & $40^{\mathrm{b}}( \pm 25)$ & $91^{\mathrm{a}}( \pm 91)$ & $100^{\mathrm{a}}$ & $100^{\mathrm{a}}$ \\
\hline
\end{tabular}

Values with letters $(a, b)$ in the same row indicate significant difference $\left({ }^{*}=P<0.05 ;{ }^{* *}=P<0.01\right)$.

+ For this option there are no significant differences between clusters when applying the Duncan test, but they do exist when applying the LSD test $(P=0.102)$.

\# Husband works in mining.

\#\# In all other cases they have primary education, all farmers have received some schooling. 
Table 2: Infrastructures, Facilities and Farm size variables (mean and standard error) for the whole study sample and each group of farms

\begin{tabular}{|c|c|c|c|c|c|}
\hline Variables & $\begin{array}{c}\text { All } \\
\text { groups }\end{array}$ & Group 1 & Group 2 & Group 3 & Group 4 \\
\hline No. Farms & 28 & 5 & 11 & 5 & 7 \\
\hline Electricity available, $\%$ & $93( \pm 5)$ & $100( \pm 0)$ & $82( \pm 12)$ & $100( \pm 0)$ & $100( \pm 0)$ \\
\hline \multicolumn{6}{|l|}{ Water available : } \\
\hline Well, \% & $25( \pm 8)$ & $40( \pm 25)$ & $18( \pm 12)$ & $20( \pm 20)$ & $29( \pm 18)$ \\
\hline Mains (drinking water), $\%$ & $7( \pm 5)$ & 0 & $9( \pm 9)$ & $20( \pm 20)$ & 0 \\
\hline Spring, river or lake, $\%$ & $68( \pm 9)$ & $60( \pm 25)$ & $73( \pm 14)$ & $60( \pm 25)$ & $71( \pm 18)$ \\
\hline Facilities (from 1 to 4 ) + & $2.8( \pm 0.2)$ & $2.4( \pm 0.4)$ & $2.8( \pm 0.3)$ & $3.4( \pm 0.2)$ & $2.7( \pm 0.4)$ \\
\hline Total farm area, ha ${ }^{* * *}$ & $257( \pm 56)$ & $157^{b}( \pm 83)$ & $201^{\mathrm{b}}( \pm 55)$ & $704^{a}( \pm 167)$ & $96^{b}( \pm 51)$ \\
\hline Grazing area, ha *** & $209( \pm 49)$ & $123^{b}( \pm 90)$ & $154^{b}( \pm 41)$ & $593^{a}( \pm 145)$ & $81^{b}( \pm 51)$ \\
\hline Scrubs and bushes, ha \# & $48( \pm 14)$ & $34( \pm 18)$ & $47( \pm 24)$ & $110( \pm 51)$ & $15( \pm 8)$ \\
\hline $\mathrm{N}$ of cows $* * *$ & $28( \pm 4)$ & $17^{\mathrm{bc}}( \pm 8)$ & $33^{\mathrm{ab}}( \pm 4)$ & $52^{\mathrm{a}}( \pm 8)$ & $10^{c}( \pm 2)$ \\
\hline $\mathrm{N}$ of ewes (all farms) \#\# & $18( \pm 5)$ & $33( \pm 21)$ & $7( \pm 3)$ & $29( \pm 16)$ & $17( \pm 5)$ \\
\hline $\mathrm{N}$ of ewes (only farms with sheep) \#\# ** & $32( \pm 7)$ & $84^{\mathrm{a}}( \pm 17$ & $16^{c}( \pm 2)$ & $49^{b}( \pm 19)$ & $20^{\text {bc }}( \pm 4)$ \\
\hline There is sheep in the farm, $\%$ & $57( \pm 10)$ & $40( \pm 25)$ & $45( \pm 16)$ & $60( \pm 25)$ & $86( \pm 14)$ \\
\hline Total Livestock Units (LU) ** & $30( \pm 4)$ & $22^{b}( \pm 11)$ & $34^{\mathrm{ab}}( \pm 4)$ & $56^{\mathrm{a}}( \pm 9)$ & $13^{b}( \pm 2)$ \\
\hline Stoking rate (LU/ha for grazing) & $0.5( \pm 0.2)$ & $1.2( \pm 1.0)$ & $0.4( \pm 0.1)$ & $0.1( \pm 0)$ & $0.4( \pm 0.1)$ \\
\hline
\end{tabular}

Values with letters $(a, b, c)$ in the same row indicate significant difference $\left({ }^{* *}=P<0.01 ;{ }^{* * *}=P<0.001\right)$.

+ One point for each of following facilities: sleeves, sheds, corrals and barns.

\# Scrub and bushes are always used for firewood collection and never for animal fodder.

\#\# It includes farms without sheep.

\#\# It includes only farms with sheep. 
Table 3: Management variables (feeding and reproduction) for the whole sample and each group of farms (cluster)

\begin{tabular}{lccccc}
\hline Variables & All groups & Cluster 1 & Cluster 2 & Cluster 3 & Cluster 4 \\
\hline No. farms & 28 & 5 & 11 & 5 & 7 \\
Cattle carry out short seasonal migration, \% & $86( \pm 7)$ & $60( \pm 25)$ & $91( \pm 9)$ & 100 & $86( \pm 14)$ \\
Uses leguminous plants in the meadows, \%\# & $32( \pm 9)$ & $20( \pm 20)$ & $27( \pm 14)$ & $60( \pm 25)$ & $29( \pm 18)$ \\
Grows oats for grain, \% \#* ${ }^{*}$ & $21( \pm 8)$ & $0^{\mathrm{b}}$ & $18^{\mathrm{ab}}( \pm 12)$ & $60^{\mathrm{a}}( \pm 25)$ & $14^{\mathrm{ab}}( \pm 14)$ \\
Makes hay, \% ** & $75( \pm 8)$ & $0^{\mathrm{b}}$ & $82^{\mathrm{a}}( \pm 12)$ & $100^{\mathrm{a}}$ & $100^{\mathrm{a}}$ \\
Concentrate purchased per LU and year, kg & $26( \pm 3)$ & $19( \pm 6)$ & $30( \pm 3)$ & $17( \pm 6)$ & $31( \pm 9)$ \\
Bales of hay $(25 \mathrm{~kg})$ purchased per LU and year & $8( \pm 1)$ & $6( \pm 4)$ & $7( \pm 2)$ & $8( \pm 3)$ & $9( \pm 3)$ \\
Does soil analyses, \% & $64( \pm 9)$ & $20( \pm 20)$ & $64( \pm 15)$ & 100 & $71( \pm 18)$ \\
Fertilises meadows, \% *** & $75( \pm 8)$ & $0^{\mathrm{b}}$ & $82^{\mathrm{a}}( \pm 12)$ & $100^{\mathrm{a}}$ & $100^{\mathrm{a}}$ \\
Separates the rams, \% & $14( \pm 7)$ & $20( \pm 20)$ & 0 & $40( \pm 25)$ & $14( \pm 14)$ \\
Separates the bulls, \% & $21( \pm 8)$ & $20( \pm 20)$ & $27( \pm 14)$ & $40( \pm 25)$ & 0 \\
Buys or exchanges males locally, \% & $54( \pm 10)$ & $60( \pm 25)$ & $64( \pm 15)$ & $20( \pm 20)$ & $57( \pm 20)$ \\
Farmer desparasite animals, \% & $93( \pm 5)$ & $80( \pm 20)$ & $91( \pm 91)$ & 100 & 100 \\
Farmer vaccinates animals, \% & $29( \pm 9)$ & $20( \pm 20)$ & $27( \pm 14)$ & $40( \pm 25)$ & $29( \pm 18)$ \\
Keeps production records, \% & $36( \pm 9)$ & $40( \pm 25)$ & $45( \pm 16)$ & $40( \pm 25)$ & $14( \pm 14)$ \\
Keeps economic records, \% & $14( \pm 7)$ & $20( \pm 20)$ & $18( \pm 12)$ & $20( \pm 20)$ & 0 \\
State and private advice, \% + & $21( \pm 8)$ & $20( \pm 20)$ & $27( \pm 14)$ & $40( \pm 25)$ & 0 \\
\hline
\end{tabular}

Values with letters $(a, b)$ in the same row indicate significant difference $\left({ }^{*}=P<0.05 ;{ }^{* * *}=P<0.001\right)$.

\# Leguminous: white clover, red clover or alfalfa.

\#\# The cattle are always on pasture, but sometimes some land is set aside to plant oats for grain.

+ In all other cases the advice is only from the State. 
Table 4: Commercialisation and Economic variables (mean and standard error) for the whole study sample and each group of farms

\begin{tabular}{|c|c|c|c|c|c|}
\hline Variables & All groups & Cluster 1 & Cluster 2 & Cluster 3 & Cluster 4 \\
\hline No. farms & 28 & 5 & 11 & 5 & 7 \\
\hline Concentrate cost, $€ / y r$ * & $220( \pm 35)$ & $132^{\mathrm{ab}}( \pm 73)$ & $317^{\mathrm{a}}( \pm 62)$ & $266^{\mathrm{ab}}( \pm 84)$ & $96^{b}( \pm 20)$ \\
\hline Farm hay cost, $€ / y r$ & $1056( \pm 282)$ & $1293( \pm 1209)$ & $1125( \pm 405)$ & $1606( \pm 604)$ & $383( \pm 124)$ \\
\hline Total feed cost, $€ /$ yr & $1275( \pm 300)$ & $1425( \pm 1280)$ & $1443( \pm 441)$ & $1872( \pm 577)$ & $479( \pm 109)$ \\
\hline Feed cost per LU, €/yr & $40( \pm 6)$ & $31( \pm 18)$ & $40( \pm 10)$ & $39( \pm 14)$ & $48( \pm 13)$ \\
\hline Rented pasture cost, $€$ & $35( \pm 35)$ & 0 & $90( \pm 90)$ & 0 & 0 \\
\hline Hired labour cost, €/yr * & $732( \pm 303)$ & $900^{\mathrm{ab}}( \pm 900)$ & $364^{b}( \pm 364)$ & $2400^{\mathrm{a}}( \pm 980)$ & $0^{\mathrm{b}}( \pm 0)$ \\
\hline Medication cost, €/yr & $49( \pm 19)$ & $0( \pm 0)$ & $89( \pm 42)$ & $17( \pm 17)$ & $44( \pm 29)$ \\
\hline Total costs, $€ / y r^{*}$ & $2092( \pm 411)$ & $2325^{\mathrm{ab}}( \pm 1403)$ & $1985^{\mathrm{ab}}( \pm 487)$ & $4289 \mathrm{a}( \pm 1006)$ & $523^{b}( \pm 122)$ \\
\hline T. costs per LU, €/yr & $70( \pm 6)$ & $91( \pm 61)$ & $62( \pm 17)$ & $88( \pm 29)$ & $55( \pm 18)$ \\
\hline Trading through an association, $\%+$ & 100 & 100 & 100 & 100 & 100 \\
\hline $\mathrm{N}^{0}$ calves sold ${ }^{* *}++$ & $22( \pm 4)$ & $12^{\mathrm{b}}( \pm 7)$ & $27^{\mathrm{ab}}( \pm 5)$ & $41^{a}( \pm 9)$ & $7^{\mathrm{b}}( \pm 1)$ \\
\hline $\mathrm{N}^{0}$ calves sold per cow & $0.76( \pm 0.05)$ & $0.64( \pm 0.07)$ & $0.79( \pm 0.09)$ & $0.79( \pm 0.15)$ & $0.78( \pm 0.13)$ \\
\hline $\mathrm{N}^{0}$ lambs sold ++ & $7( \pm 3)$ & $18( \pm 13)$ & $3( \pm 1)$ & $8( \pm 6)$ & $5( \pm 2)$ \\
\hline $\mathrm{N}^{0}$ lambs sold per ewe & $0.35( \pm 0.04)$ & $0.52( \pm 0.16)$ & $0.35( \pm 0.06)$ & $0.33( \pm 0.23)$ & $0.29( \pm 0.06)$ \\
\hline Total sales, $€ / y r$ ** & $9399( \pm 1533)$ & $6368^{b}( \pm 3926)$ & $11074^{\mathrm{ab}}( \pm 2181)$ & $17333^{a}( \pm 3756)$ & $\begin{array}{l}3264^{b} \\
( \pm 432)\end{array}$ \\
\hline T. sales per LU, €/yr & $296( \pm 21)$ & $248( \pm 33)$ & $316( \pm 34)$ & $307( \pm 56)$ & $290( \pm 49)$ \\
\hline Farm profit, $€ / y r^{*}$ & $7307( \pm 1377)$ & $4043^{\mathrm{ab}}( \pm 2963)$ & $9089 \mathrm{ab}( \pm 1998)$ & $13044^{a}( \pm 4524)$ & $\begin{array}{l}2740^{\mathrm{b}} \\
( \pm 491)\end{array}$ \\
\hline Profit per LU, $€ / y r$ & $226( \pm 25)$ & $156( \pm 70)$ & $254( \pm 39)$ & $220( \pm 78)$ & $234( \pm 40)$ \\
\hline INDAP or private loans, $\%+++$ & $11( \pm 6)$ & $20( \pm 20)$ & $0( \pm 0)$ & $40( \pm 25)$ & $0( \pm 0)$ \\
\hline
\end{tabular}

Values with letters $(a, b)$ in the same row indicate significant difference $\left({ }^{*}=P<0.05 ;{ }^{* *}=P<0.01 ;{ }^{* * *}=P<0.001\right)$

+ All farmers purchase feed and sell animals through a unique association (Asociación Gremial "Bajada Ibáñez");

++ The animals are always sold after weaning; +++ INDAP: Intituto de Desarrollo Agropecuario. In all other cases the loan is only from INDAP

\section{- Statistical analysis}

The data on the variables were subjected to multivariate analysis in two stages: principal component analysis (PCA) and cluster analysis (CA) ${ }^{(15)}$. PCA transforms the data on the diagnostic variables studied into a small set of new synthetic variables - principal components (PC) - with little loss of information. The purpose of PCA is therefore to reduce the number of variables and thus the dimensions of the problem ${ }^{(16,17)}$. The method used for 
PCA was the optimal scaling analysis which is used when the variables analyzed are both qualitative and quantitative variables ${ }^{(15)}$.

Before the multivariate analysis the number of variables was reduced excluding those with a low variability coefficient $(<50 \%)$ and therefore little discriminatory capacity ${ }^{(18)}$, as were those which correlated with others considered by the authors to be more important for defining the production system ${ }^{(17)}$. During the process of reducing variables, 31 of the 44 variables used in the study were discarded. Therefore, 13 variables were used to perform the discriminant analysis which was started checking the appropriate number of PCs, as well as the variables attached to these PCs, in order to obtain the best and most synthetic explanation of the existing variability. In order the PCs to be sufficiently representative of the set of variables, the eigenvalues were required to be greater than $1^{(16)}$.

After PCA, the farms were classified by K-means type CA. In this case, this type of CA is better than the hierarchical, because authors know what the number of cluster do not can be high. The PCs obtained in the first part of the multivariate analysis were used for the CA instead the conjoint of variables ${ }^{(17)}$. Finally, once the different clusters are obtained, they can be described and afterward compared using one-way ANOVA for each of the original variables. With this analysis the multivariate analysis is confirmed ${ }^{(15)}$. For all variables were calculated the mean and standard error. In the case of qualitative variables the mean coincides with the relative frequency of value 1 , ranging the presented results from 0 to $100 \%$. For variables with significant differences, the multiple comparison post hoc test was applied (Duncan). All the statistical analyses were carried out with the IBM SPSS Statistics 20 statistical package ${ }^{(19)}$.

\section{Results}

\section{- Principal component analysis (PCA) and cluster analysis (CA)}

From the optimal scaling analysis (PCA), three principal components were obtained, being the eigenvalues 3.125 for the first PC, 2.158 for the second and 1.210 for the third. The 
relative variances were $34.7,24.0$ and 13.4 respectively, explaining $72.1 \%$ of the total variance. The first PC named 'Farm size' includes the variables total area, number of cows, total costs and total sales. The second PC named 'Farm management' includes the variables person in charge of the farm, farmer makes hay and farmer fertilises meadows. The third PC named 'Producer's age and Number of ewes' includes these two variables. The eigenvectors (weights) for each of the nine variables according to the three PCs are shown in Table 5.

Table 5: Eigenvectors (weights) by the three principal components (PC)

\begin{tabular}{lcccccc}
\hline & PC1 & P value & PC2 & P value & PC3 & P value \\
\hline Producer's age & -0.324 & Ns & -0.370 & ns & 0.731 & $* * *$ \\
Total area & 0.729 & $* * *$ & 0.114 & $\mathrm{~ns}$ & 0.289 & $\mathrm{~ns}$ \\
Number of cows & 0.885 & $* * *$ & -0.103 & $\mathrm{~ns}$ & -0.049 & $\mathrm{~ns}$ \\
Number of ewes & 0.272 & $\mathrm{~ns}$ & 0.390 & $\mathrm{~ns}$ & 0.719 & $* * *$ \\
Total costs & 0.826 & $* * *$ & 0.171 & $\mathrm{~ns}$ & 0.025 & $\mathrm{~ns}$ \\
Total sales & 0.910 & $* * *$ & -0.091 & $\mathrm{~ns}$ & -0.096 & $\mathrm{~ns}$ \\
Person in charge of the farm & -0.186 & $* * *$ & -0.495 & $* * *$ & 0.245 & $\mathrm{~ns}$ \\
Farmer fertilises meadows & -0.232 & $\mathrm{~ns}$ & 0.887 & $* * *$ & 0.041 & $\mathrm{~ns}$ \\
Farmer makes hay & -0.186 & $\mathrm{~ns}$ & 0.881 & $* * *$ & 0.027 & $\mathrm{~ns}$ \\
\hline
\end{tabular}

As a result of the subsequent cluster analysis four clusters were found: C1, C2, C3 and C4, containing 5, 11, 5 and 7 LPU respectively. Figure 2 shows the distribution of the LPU among the three principal components (PC). 
Figure 2: Clustered farms plotted according to the principal components 1-2 and 1-3

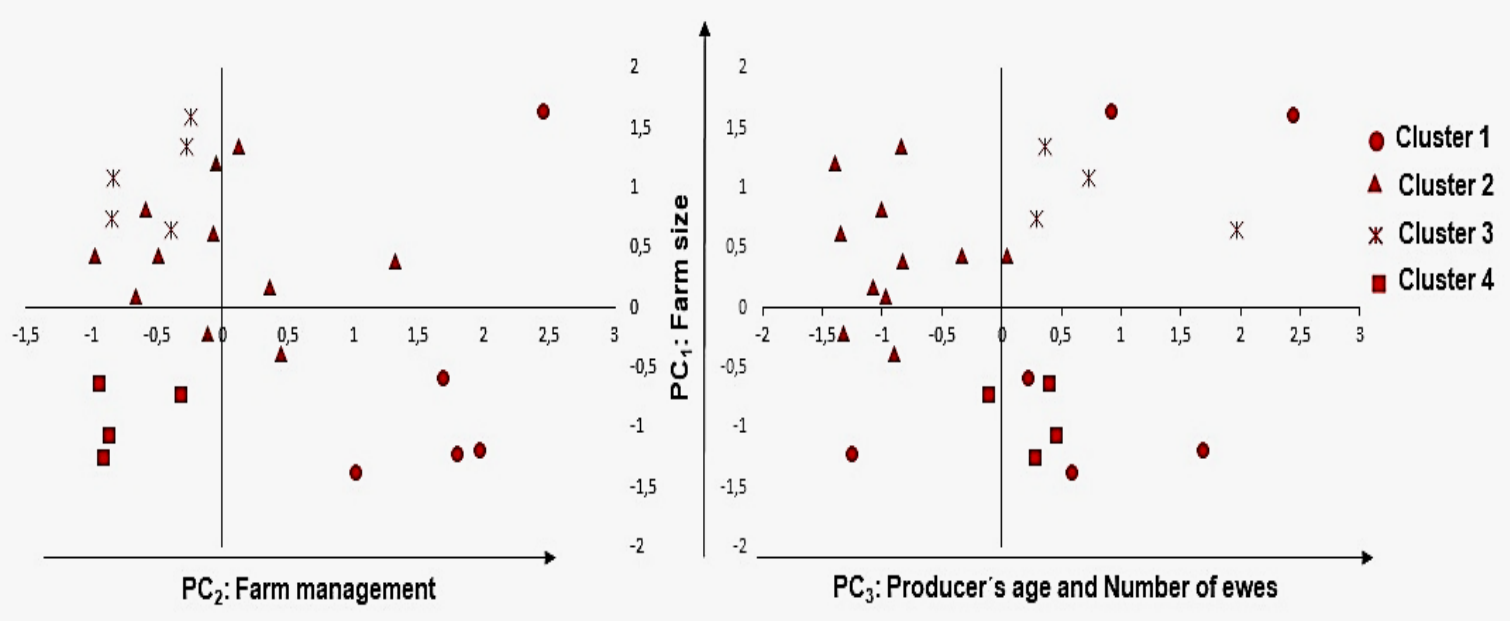

Finally it was applied ANOVA to differentiate the effects of the groups obtained in each of the original variables, thus confirming the multivariate analysis. Results for each variable are showed on Tables 2 to 5 .

\section{- Characteristics of the LPU clusters}

Below are described the principal characteristics of the four clusters obtained:

C1 (5 farms): Middle aged producers with high proportion of women. Moderately low LPU size and low economic results. Deficient farm management. Producers are women living alone in $80 \%$ of cases. Herds have only 17 cows but 84 ewes (mean of farms having sheep). Farms have 123 ha of grazing, having the higher stoking rate (1.2 livestock units, LU/ha). The mean of the farm profit is $4,043 €$ per year. The farm management is deficient in relation to animal feeding (farmer do not makes hay, do not fertilises meadows) and to the reproduction.

C2 (11 farms): Young producers with medium proportion of women. Medium LPU size and economic results. Medium farm management. Producers are women living alone in $45 \%$ of cases or husband runs the farm in $46 \%$ of cases. Herds have 33 cows and only 16 ewes (mean of farms having sheep). Farms have 154 ha of grazing area. The mean of the farm profit is $9,089 €$ per year, having relatively low costs. The farm management is moderately good in relation to animal feeding and deficient to the reproduction. 
C3: Elderly producers with medium proportion of women. Relatively high LPU size and good economic results. Moderately good farm management. Producers are women living alone (20\%) or running the farm because the husband works in mining $(20 \%)$, in the rest of cases $(60 \%)$ the husband runs the farm. Herds have 52 cows and 49 ewes (mean of farms having sheep), the higher quantity of ewes together the cluster 1. Farms have 593 ha of grazing area, the highest of all clusters, being the stocking rate the lower $(0.1 \mathrm{LU} / \mathrm{ha})$. The mean of the farm profit is $13,044 €$ per year, having the highest sales $(17,333 €$ per year) but also the highest cost by consequence of the hired labour costs $(2,400 €$ per year). The farm management is good in relation to animal feeding and is medium in relation to the reproduction.

C4: Elderly producers with medium proportion of women. Low LPU size and very poor economic results. Moderately deficient farm management. Producers are women living alone (14\%) or running the farm because the husband works in mining $(29 \%)$, in the rest of cases $(57 \%)$ the husband runs the farm. Herds have only 10 cows and 20 ewes (mean of farms having sheep), the lower quantity of ewes but they are present in $86 \%$ of farms. Farms have 81 ha of grazing area, the lowest of all clusters. The mean of the total costs, the total sales and the farm profit are the lowest of the all clusters (523, 3,264 and 2,740 $€$ per year respectively). The farm management is moderately good in relation to animal feeding and deficient in relation to the reproduction.

\section{\| Discussion \|}

The discussion is presented according to different groups of variables which were established in the methodology. After this discussion, some strategies for improving production systems are exposed.

\section{- Variables linked to sociological aspects}


Clusters C3 and C4, which include the largest and smallest farms respectively, contain the oldest farmers (around $60 \mathrm{yr}$ ), who also have the lowest level of education (60 and $86 \%$ respectively only attended primary school). That coincides with the results of a study done in the Center of Chile ${ }^{(3)}$. In this sense, one cause of the migration of the young population in Chile is the need for education ${ }^{(20)}$. Nevertheless it is encouraging to see that in cluster C2 which includes the greatest number of farms (11) there are younger farmers (39 yr old average) with a high level of education ( $82 \%$ ) compared to other countries. In many areas of Latin America (LA) as in Ecuador with goat production ${ }^{(21)}$ or in Mexico (Veracruz and Morelos) with cattle ${ }^{(1,22)}$, the education of farmers is low, around $80 \%$ have only primary education. Concerning the training courses done by farmers, the proportion in C3 (100\%) and C4 $(29 \%)$ are the higher and the lower respectively. In general, specialized training is low in the agricultural and rural areas of $\mathrm{LA}^{(2,23)}$.

As for the territorial base, $64 \%$ are owned by the farmer, but there is only one farm in $\mathrm{C} 2$ that had leased pastures. It should be noted that, except in $\mathrm{C} 3$, there is a proportion of farms, around $15 \%$, that are in the process of inheritance and that in C3 $40 \%$ of farms belong to the family group. This last has a positively influence to avoid the division of the farm when an inheritance process is come. In the central area of Chile ${ }^{(3)}$ and in Colombia ${ }^{(24)}$, ownership of land by farmer is the most common option. In other countries as Ecuador with goat production systems, the proportion of owner is low $(22 \%)^{(21)}$.

The farm work is generally done by the family members, except in C3, group of large farms, where $60 \%$ have hired hand. This situation is similar in small or medium-sized farms of less favoured regions ${ }^{(2,6)}$.

Fifty three (53) \% of the farmers running the farms are women $(80 \%$ in $\mathrm{C} 1)$. This proportion is higher than the Chilean average $(24 \%)^{(25)}$; although in Chile there is a large increase in women engaged in agriculture ${ }^{(23)}$. There is also a high proportion of women farmers in milk goat production on the Peruvian coast ${ }^{(2)}$, but that is in general infrequent in other parts of the world as in the state of Veracruz (Mexico) $^{(1)}$ where $94 \%$ are men.

The number of family members is higher than 3.4 (mean 4.2). That is similar to other areas of meat ruminant production ${ }^{(21,22)}$. In the SA, $86 \%$ of the farmers believe that their farm will continue in the hands of future generations. This value indicates that in the SA the problem of depopulation is not as serious as in rural areas in Chile in general ${ }^{(23)}$. However, in $\mathrm{C} 1$ only $40 \%$ of farmers believe that their farms will continue. In this cluster $80 \%$ of farms are running by an alone women with no other income in the family unit than the livestock activity. 


\section{- Variables regarding to infrastructure, facilities and farm size •}

Almost all the farms in the study have electricity (93\%); this value is similar for meat goat production systems of Ecuador ${ }^{(21)}$. The drinking water supply is very deficient, only $7 \%$ of farms; in other studies done in LA, as in the meat goat production systems of Ecuador are found better results ${ }^{(21)}$. The level of facilities is medium (2.8 out of 4$)$; it is higher in the cluster C3 (3.4) where farms have higher size farms.

Sheep are reared in 16 of the 28 LPU studied, while all have cattle. The number of ewes per farm is low (mean 18) ranging in farms having sheep from $16(\mathrm{C} 2)$ to $84(\mathrm{C} 1)$. The number of cows per farm is 28 ranging from $10(\mathrm{C} 4)$ to 52 (C3). Consequently, the cattle production is much more important than the sheep production. The same is true for most of LA, as in the states of Veracruz and Morelos (Mexico) ${ }^{(1,22)}$; however in the central area of Chile the ovine production predominates with respect to the bovine ${ }^{(3)}$. In the present study, the grazing area is quite high (the stocking rate is only $0.5 \mathrm{LU} / \mathrm{ha}$ ). In C3 there is the higher grazing area (593 ha); in this group there is also the lowest stocking rate $(0.1 \mathrm{LU} / \mathrm{ha})$ and the highest surface of scrubs and bushes (110 ha). Farms of the ovine and bovine systems of central Chile have a grazing area slightly lower than in the SA (160 ha) and a similar LU (34) ${ }^{(3)}$, so the stocking rate is slightly high. The stocking rate in the SA is also higher than in other zones of LA, as in the state of Veracruz (Mexico) ${ }^{(22)}$ (around $\left.1 \mathrm{LU} / \mathrm{ha}\right)^{(1)}$, in the state of Morelos (Mexico) (8 LU/ha with cattle partially in cowshed) and in la Pampa, Argentina, with extensive cattle systems for fattening $(1.8 \mathrm{LU} / \mathrm{ha})^{(26)}$.

\section{- Variables regarding to farm management}

A high proportion of farmers in SA produce hay in the farm $(75 \%)$, except in $\mathrm{C} 1$ where no farmer does it, although the stocking rate in this group is the higher (1.2). However they purchased eight bales of hay per LU and year in average $(25 \mathrm{~kg}$ each, therefore $200 \mathrm{~kg})$. The amount of concentrate purchased per LU is considerably lower than that of hay $(26 \mathrm{~kg}$ per 
LU and year in average). Considering the whole of the purchase of concentrate and hay, in $\mathrm{C} 1$ farmers purchase the lower quantity and in $\mathrm{C} 4$ the higher $(19 \mathrm{~kg}$ and 6 bales and $31 \mathrm{~kg}$ and 9 bales respectively). In C3 the whole of the purchase is similar to in C2 (medium). However, the amount purchased in $\mathrm{C} 3$ might have been lower than in $\mathrm{C} 2$ if grazing management would have been better for two raisons: in C3, $60 \%$ of farmers grow oats for grain while this percentage is very low for the other groups and in this group, as said, there is the lowest stocking area ( 0.1 vs 0.5 of study mean). Anyway in general in the SA, animal feeding is based on extensive grazing; as in the whole of central and southern Chile, in the critical periods of winter and summer the pastures do not provide sufficient nutrients ${ }^{(27)}$. When pasture is scarce (in summer), herds are moved up to land at higher altitude, involving a short migration of maximum $10 \mathrm{~km}$ (Table 4). This activity is practiced in other parts of the world with extensive livestock as Mexico ${ }^{(28)}$ Peru $^{(2)}$ or Spain ${ }^{(7)}$. The pasture shortage at some times of the year occurs in many marginal areas ${ }^{(16)}$. Instead, in the state of Veracruz (Mexico) in dual-purpose cattle farms, there is a group of business or specialist farms which produce grass and forage from improved meadows ${ }^{(1)}$. The climate in this zone enables farmers to obtain grass and forage over a longer period of the year than in the SA.

In terms of fertilisation of meadows as well as soil analyzes, farmers of $\mathrm{C} 1$ do this activities in lower proportion that in the rest of groups. As mentioned before, in $\mathrm{C} 1$ the proportion is also the lowest for haymaking, so in this group the farmers used the most deficient technology. In the whole of the study only $32 \%$ use leguminous plants. This is in agreement with the fact that pasture is an activity that is little carried out in Chile's pastoral livestock systems $^{(29)}$.

There is little control over reproductive management; the males are separated from the females outside the breeding season in only $14 \%$ of cases for sheep and $21 \%$ for cattle. However, in C4 they are separated in $40 \%$ of cases (although without significant differences with other groups). In sheep meat systems in Colombia, the period of stay of males with females and mating protocols depend on the availability of facilities and the number of males per herd ${ }^{(24)}$. In the cattle production of Ecuador, farmers do not plan the mating process ${ }^{(4)}$.

As aid in results of study, $93 \%$ of the farmers desparasite their animals, but only $29 \%$ vaccinate. In the SA these proportions are $76 \%$ and $34 \%$ respectively in $2011^{(30)}$. In other parts of LA most farmers desparasite animals, for example in states of Morelos and Veracruz (Mexico $^{(22,28)}$ or in sheep systems of Colombia ${ }^{(24)}$. To the contrary, vaccinations are less frequent and depend heavily on the technification of farms ${ }^{(28)}$. Concerning the collection of farm data there is little difference between groups, in average $36 \%$ of farmers kept production records and $14 \%$ economic records. Technical and economic management is also poor in other countries of LA such as Mexico ${ }^{(28)}$ and in Spanish goat pastoral systems ${ }^{(16)}$. Farmers received some advice from the State, but only $21 \%$ also receive private advice. 


\section{- Commercialisation and economic variables •}

In studied farms the animals are always sold after weaning. Calves are sold to fatteners or in other areas, which results in a loss of potential income. The animal sales as well as the feed purchase are made by farmers through a unique association. Selling weaned animals is common practice in Chile ${ }^{(31)}$; as well as other countries - for example both calves and lambs in Spain ${ }^{(7)}$, lambs in Veracruz, Mexico ${ }^{(28)}$; and calves in Chiapas, Mexico ${ }^{(32,33)}$. Cattle are almost all sold, although some are kept for self-provisioning on the farm; in contrast an important part of the produced lambs are kept for family consumption. This type of selfprovisioning is common in Chile ${ }^{(31)}$, just as in the state of Veracruz (Mexico) ${ }^{(28)}$. Farmers sold a mean of 0.76 calves per cow and year (the lowest value is 0.64 in $\mathrm{C} 1$ ) and only 0.35 lambs per ewe and year (the highest is 0.52 in $\mathrm{C} 1$ ), there being no significant differences. In Chile's more intensified systems, lamb production can reach 1 lamb / ewe and year ${ }^{(3)}$.

Finally economic variables are discussed. It is interesting to compare the values of costs, sales and profit per LU in order to analyze the economic efficiency, and also the farm profit (i.e. the family incomes). The mean of total feed cost per LU is $40 € / y r$, ranging from 31 and $48 € / \mathrm{yr}$ in $\mathrm{C} 1$ and $\mathrm{C} 4$ respectively, without significant differences between groups, being medium values in C2 and C3 (40 and $39 € / y r$ respectively). This agrees with the discussion about the management variables. With respect to the hired labour cost is very high in $\mathrm{C} 1$ and C3 (900 and 2,400 €/yr respectively). These high values are due to a different raison for each two groups: in C3 farms had a much larger size than in the others groups and in $80 \%$ of cases of $\mathrm{C} 1$ an alone woman runs the farm. By consequence, in $\mathrm{C} 1$ and $\mathrm{C} 3$ there are the highest total cost per LU (91 and 88 respectively being $70 € /$ yr the mean of study). In Colombian sheep production $^{(24)}$, the cost of labor is important with respect to the cost of feeding on farms that have fewer animals and the opposite occurs in those with more animals; but in general in the systems of production of ruminants the feeding is the most important $\operatorname{cost}^{(26)}$.

The total sales per LU ranged from 248 and $316 € / \mathrm{yr}$ in $\mathrm{C} 1$ and $\mathrm{C} 2$ respectively; in $\mathrm{C} 3$ and C4 the value are similar that in C2 (307 and $290 € / y r$ respectively). These in general low values could be due, among other factors, to the familiar consumption of a part of produced animals, especially of lambs, or to the deficient farm management (reproduction or feeding). This last aspect is particularly important in $\mathrm{C} 1$ where as mentioned there is the most deficient feeding management of study (at the same time there are a high stocking rate, no production 
of hay and little feed purchase). In the Mexican state of Morelos ${ }^{(22)}$ with a similar number of dual-purpose cows per farm (45), the total income is similar to that found in the present study; however as the stocking rate area of pasture in the Morelos study is very small (only 9 ha/farm), the production costs are much higher.

The profit per LU ranges from 156 to $254 € / \mathrm{yr}$ in $\mathrm{C} 1$ and $\mathrm{C} 2$ respectively. The farm profit of the study is not very high, ranging from 2,740 to $13,044 € / \mathrm{yr}$ in C4 and C3 respectively; however it is much higher than obtained in the cattle production of Chiapas (Mexico) (923 $€ / y r$ ); having a mean of seven cows per farm and a profit per LU of $130 € / \mathrm{yr}^{(33)}$. In $\mathrm{C} 4$ the profit per LU is almost so high than in C2 (234 €/yr) but the very low quantity of LU (13 in average) lead to a very low farm profit (family income). This very low income obtained in C4 is compensated in $29 \%$ of the cases with the income that the husband of the woman farmer obtains working in the mine. In $\mathrm{C} 1$, the farm profit is also quite low $(4,043)$ by consequence of the low profit per LU and the deficient farm management which lead, as said, to a low proportion of farmers believing that the farm will continue for future generations (only $40 \%$ ). In $\mathrm{C} 2$ the farm profit is medium $(9,089 € / \mathrm{yr})$ although the profit per LU is the highest because the LU value is also medium (34). Instead, in C3, the farm profit is the highest although the profit per LU is medium (220€/yr) because the LU value is also the highest (56). Consequently in C2 and C3 there is a moderately adjusted economic activity, being more adjusted in $\mathrm{C} 2$ due mainly to in $\mathrm{C} 3$ the hired labour cost is very high. In $20 \%$ of cases of this last group, this high hired labour cost could be explained by the fact that the husband works in the mine (thus complementing family income).

The majority of farmers ( $89 \%$ ) only had public loans from the Intituto de Desarrollo Agropecuario (INDAP) to pay for investments ${ }^{(34)}$. Only in the larger farms (C3) which have better facilities some farmers also hold loans from private entities (40\%).

\section{- Strategies for improving production systems}

The stoking rate could increase in C3, even goats could be introduced into the farms of this group to take advantage of scrubs and bushes $(110 \mathrm{ha})^{(16)}$. In the other groups it is not clear whether it is desirable to increase the stocking rate, especially in $\mathrm{C} 1$ (where the current value is $1.2 \mathrm{LU} / \mathrm{ha}$ ). In order not to diminish the size of the farms, the farmers should try to accelerate the inheritance process and try to increase the farms belonging to the family group 
(as in C3). It must be studied the convenience in some farms (those with better pastures) the production of milk destined to produce cheese for the market.

Farmers in all the clusters need to improve their water infrastructure, since in $68 \%$ of the cases they had only water of spring, river or lake. In all clusters, although less in C3, facilities should be improved; for instance better stables could favorise the giving births.

In all clusters it would be necessary to plan the mating periods, so that when the majority of mothers have the highest nutritional needs (during lactation), there is a greater availability of natural pasture ${ }^{(16)}$. In general, efforts should be made to increase productivity and therefore the number of animals sold, especially in $\mathrm{C}^{(8)}$. Also, farmers should increase the cultivated area destined to obtain hay or grain, especially in $\mathrm{C} 1$ where no farmer has these crops ${ }^{(16)}$. The quality of pasture should also be improved (using more leguminous plants) in C2 and C4 and especially in $\mathrm{C} 1$; also in this last group would fertilize the pastures. In terms of sanitary management of livestock, it should be improved, especially by carrying out more vaccinations; the Servicio Agrícola y Ganadero of Chile (SAG) increased from 2013 the aid to apply vaccines and deworming to cattle in the Commune of Rio Ibáñez (SA) ${ }^{(35)}$.

In the present study, the INDAP (Instituto de Desarrollo Agropecuario) offered the majority of advice and training services and likewise the loans (Tables 4 and 5). As all marginal areas, these services (whether public or private) are essential ${ }^{(16)}$. In addition, among the objectives of INDAP there are other aspects that are of interest for the improvement of the farms of this study ${ }^{(34)}$ : installation of young and women as farmers, marketing (including the added value of productions), off-farm activities (rural tourism and handicrafts) ${ }^{(1)}$ and promotion of associationism in different aspects. The work of farmers in other economic activities could improve the family incomes; but, it is not always clear whether this employment is complementary and compatible with their own farm work or could suppose a threat and a loss of commitment, which could eventually lead them to abandon the farm ${ }^{(7)}$.

To improve commercialisation the only existing association needs to become more active, or other associations need to be created ${ }^{(8,33)}$. It could be studied whether breeders could participate in some way in fattening weaned animals ${ }^{(7,32)}$ or at least could have an animal typing centre that would allow them to obtain better sales prices. Sending the animals away for fattening is also an obstacle to obtain differentiated quality products sold if possible in short commercial circuits ${ }^{(12,32,34)}$. In this sense, studies about the meat quality according the animal feeding, have been done in Chile ${ }^{(10)}$. Policies and institutional arrangements should be strengthened to favorise the farm production commercialization ${ }^{(8)}$; the creation of an Protected Area: public-private inter-institutional networks capable of promoting rural development processes ${ }^{(6)}$ could be interesting to solve this commercialisation problem. 


\section{Conclusions and implications}

The cattle and sheep farms of southern Chile located in difficult or marginal areas are integrated in pasture-based livestock systems, having a medium-low use of external resources. The groups obtained from the classification show that variations between groups are due to the farm size, age and personal situation of farmers, farm management and farm profitability. Farms in charge of young farmer having a good education level, with very low number of sheep, have the highest profitability (profit per LU and year) although without significant differences. The main problems found, in general, are the low productivity of the herds and the poor marketing channels of animal products. Smallest farms are the ones that have more difficulties in general, a poorer management and a lower profit, so that they have less possibility to continue in the future.

To address these problems and ensure the viability and continuity of these production systems, Government help is required in the form of training, advice, financial support and promotion of associationism. Diversification of the farm's activities by all members of the farmer's family can contribute to the family economy.

\section{Acknowledgements}

To Innova-CORFO Project 11 NTEC 12793 "NODO RÍO IBÁÑEZ”, for funding. To the farmers who took part in the study for their cooperation.

\section{- Literature cited}


1. Vilaboa J, Díaz, P. Caracterización socioeconómica y tecnológica de los sistemas ganaderos en siete municipios del estado de Veracruz, México. Zootecnia Trop 2009;(27):427-436.

2. Sarria JA, Ruiz FA, Mena Y, Castel JM. Characterization of goat production systems of the Peruvian coast. Prospects for improvement. Rev Mex Cienc Pecu 2014;5(4):409427.

3. Toro-Mujica P, Aguilar C, Vera R, Rivas J, García, A. Sheep production systems in the semi-arid zone: Changes and simulated bio-economic performances in a case study in Central Chile. Livest Sci 2015;(180):209-219.

4. Ríos-Núñez S, Benítez-Jiménez D. Análisis del funcionamiento económico productivo de los sistemas de producción cárnica bovina en la Amazonía Ecuatoriana. Arch Zootec 2015;64(248):409-416.

5. Udo HMJ, Aklilu HA, Phong LT, Bosma RH, Budisatria IGS, Patil BR et al. Impact of intensification of different types of livestock production in smallholder crop-livestock systems. Livest Sci 2011;(139):22-29.

6. Paz R, Bruno R. The potential of family agriculture and protected spaces: guidelines for public policies design. Mundo Agrario 2013;(13):1515-5994.

7. Bernués A, Ruiz R, Olaizola,A, Villalba D, Casasús I. Sustainability of pasture-based livestock farming systems in the European Mediterranean context: synergies and tradeoffs. Livest Sci 2011;(139):44-57.

8. Iñiguez $\mathrm{L}$. The challenges of research and development of small ruminant production in dry areas. Small Rumin Res 2011;(98):12-20.

9. Acosta A, Díaz T (editor). Lineamientos de Política para el Desarrollo Sostenible del Sector Ganadero. Ciudad de Panamá, Panamá: Oficina Subregional de la FAO para Mesoamérica; 2014. http://www.fao.org/3/a-i3764s.pdf. Consultado Sep 24, 2016.

10. Morales R, Folch C, Iraira S, Teuber N, Realini C. Nutritional quality of beef produced in Chile from different production systems. Chilean J Agric Res 2012;72(1):80-86.

11. ODEPA (Oficina de Estudios y Políticas Agrarias). Gobierno de Chile. Boletín carne bovina: tendencias de producción, precios y comercio exterior; 2016. http://www.odepa.cl/wp-content/files_mf/1464627671boletinCarne201605.pdf.

Consultado Sep 24, 2016. 
12. Vilaboa J, Díaz P, Platas DE, Ruiz O, González, SS, Juárez F. Commercialisation structure of cattle destined for meat supply in the region of Papaloapan, Veracruz, Mexico. Economía, Sociedad y Territorio 2009;(31):831-854.

13. Gobierno de Chile. Estrategia Regional de Desarrollo de Aysén. Chile: Gobierno Regional de Aysén; 2009. http://www.subdere.gov.cl/documentacion/aysen-estrategiade-desarrollo-regional-periodo-2009-2030. Consultado Abr 8, 2017.

14. INE (Instituto Nacional de Estadística). Encuesta de Ganado Bovino. Gobierno de Chile; 2007. http://nuevoportal.ine.cl/estadisticas/censos/censo-agropecuario-y-forestal-2007. Consultado Abr 8, 2017.

15. Madry W, Mena Y, Roszkowska-Madra B, Gozdowski D, Hryniewski R, Castel JM. An overview of farming system typology methodologies and its use in the study of pasturebased farming system: a review. Span J Agric Res 2013:11(2):316-326.

16. Ruiz FA, Castel JM, Mena Y, Camúñez J, González-Redondo P. Application of the technico-economic analysis for characterizing, making diagnoses and improving pastoral dairy goat systems in Andalusia (Spain). Small Ruminant Res 2008;(77):208220.

17. Lesschen JP, Verburg P, Staal S.J. Statistical methods for analyzing the spatial dimension of changes in land use and farming systems. Wageningen, The Netherlands: Wageningen University; 2005.

18. Hair JF, Anderson RE, Tatham RL, Black WC. Multivariate data analysis. 5th ed. New Jersey, USA: Prentice Hall International; 1998.

19. IBM. Manual del usuario del sistema básico de IBM SPSS Statistics 20. Armonk, New York, USA: IBM Corporation; 2011.

20. Cicarelli A. Caracterización agropecuaria de pequeños productores mapuches de la reducción indígena Francisco Paillal, Galvarino, Región de la Araucanía [tesis de grado]. Temuco, Chile: Universidad Católica de Temuco; 2011.

21. Villacrés J, Ortega L, Chávez D. Caracterización de los sistemas de producción caprinos, en la provincia de Santa Elena. Revista Científica y Tecnológica UPSE 2017;4(2):9-19.

22. Chalate-Molina H, Gallardo F, Pérez-Hernández P, Lang FP, Ortega E, Vilaboa J. Características del sistema de producción bovinos de doble propósito en el estado de Morelos, México. Zootecnia Trop 2010;28(3):329-339. 
23. Fawaz J, Vallejos R. Calidad de vida, ocupación, participación y roles de género: un sistema de indicadores sociales de sostenibilidad rural (Chile). Cuad Desarro Rural 2011;8 (67):45-68.

24. Parra RI, Magaña MA, Duarte JH, Téllez G. Caracterización técnica y rentabilidad de granjas ovinas con visión empresarial del departamento del Tolima. Rev Colombiana Cienc Anim 2014;7(1):64-72.

25. ODEPA (Oficina de Estudios y Políticas Agrarias). Gobierno de Chile; 2009. http://www.odepa.gob.cl/odepaweb/publicaciones/doc/2196.pdf. Consultado Sep 21, 2016.

26. Castaldo A, Acero R, Perea J, Martos J, Valerio D, Pamio J et al. Tipología de los sistemas de producción de engorde bovino en la Pampa Argentina. Arch Zootec 2006;55(210):183-193.

27. Catrileo, A. Producción y manejo de carne bovina en Chile. Chile: INIA (Instituto de Investigaciones Agropecuarias). 2005.

28. Pérez-Hernández P, Vilaboa J, Chalate H, Candelaria B, Díaz-Rivera P, López-Ortiz S. Análisis descriptivo de los sistemas de producción con ovinos en el Estado de Veracruz, México. Revista Científica 2011;21(4):327-334.

29. Rodríguez-Rodríguez PR. Respuesta productiva en praderas a la aplicación de fertilizante Nutriterra en la comuna de La Unión, Región de Los Ríos - Chile [tesis de grado]. Valdivia, Chile: Universidad Austral de Chile; 2011.

30. SAG (Servicio Agrícola y Ganadero). Gobierno de Chile. Boletin Veterinario Oficial. Región de Aysén; 2011. https://www2.sag.gob.cl/pecuaria/bvo/bvo_13_i_semestre_ 2011/PDF_articulos/uso_conocim_med_vet_TChacon.pdf. Consultado Sep 21, 2016.

31. Goic L, Rojas C. Sistema de crianza, de recría y engorda en la zona sur. Rojas C editor. Manual de producción de bovinos de carne para la VIII, IX y X regiones. Temuco, Chile: INIA; $2004: 95-135$.

32. Calderón J, Nahed J, Sánchez B, Herrera O, Aguilar R, Parra M. Estructura y función de la cadena productiva de carne de bovino en la ganadería ejidal de Tecpatán, Chiapas, México. Avances en Investigación Agropecuaria 2012;16(2):45-61.

33. Aguilar JR, Nahed J, Valdivieso A, Sánchez B, Mijangos SJ. Análisis multidimensional de la ganadería bovina en la cuenca alta y media del río Grijalva. En: González EM, Brunel MC editors. Montañas, pueblos y agua: Dimensiones y realidades de la cuenca Grijalva. México: Juan Pablos editor/ECOSUR; 2015:378-405. 
34. INDAP (Instituto de Desarrollo Agropecuario). Ministerio de Agricultura de Chile. Gobierno de Chile; 2014. http://www.indap.gob.cl/docs/default-source/LineamientosEstrat\%C3\%A9gicos/lineamientos-estrategicos-2014-2018-vf.pdf?sfvrsn=0.

Consultado Sep 21, 2016.

35. SAG (Servicio Agrícola y Ganadero). Gobierno de Chile; 2013. http://www.sag.cl/noticias/sag-extiende-programa-de-manejo-sanitario-bovino-lascomunas-de-chile-chico-e-ibanez. Consultado Sep 21, 2016. 